\title{
Foreign Direct Investment and Economic Growth during Financial Liberalization Episodes
}

\author{
Quang Ngoc Nguyen ${ }^{1}$, Toan My Pham ${ }^{1} \&$ Ramaprasad Bhar ${ }^{1}$ \\ ${ }^{1}$ The University of New South Wales, Australia \\ Correspondence: Ramaprasad Bhar, The University of New South Wales, Australia. E-mail: r.bhar@unsw.edu.au
}

Received: April 8, 2014

Accepted: May 22, 2014

Online Published: July 25, 2014

doi:10.5539/ijef.v6n8p91

URL: http://dx.doi.org/10.5539/ijef.v6n8p91

\begin{abstract}
This paper investigates the relation between foreign direct investment and economic growth under the effects of the financial liberalization processes. The paper focuses on the emerging markets, where the flows of foreign direct investment are most active and the financial liberalization processes are most intensifying. Analysis of 24 emerging markets over the 1980-2004 period shows that the easing of short-term capital flows diminishes the positive effects of foreign direct investment. The finding has important implications for policy makers in emerging markets.
\end{abstract}

Keywords: foreign direct investment, capital flows, financial liberalization, economic growth

\section{Introduction}

Together with the increasing pace of globalization, the debate about the benefits of international capital flows is becoming intensifying. While most studies generally agree on the potential benefits of foreign direct investment (FDI) and the dangers of short-term capital flows (e.g., Stiglitz, 1999, 2000, 2004), they often look at the effects of the various types of international capital flows in isolated cases. In this paper, we analyze the contemporaneous effects of long-term versus short-term capital flows using an ideal natural setting: financial liberalization in emerging markets (Note 1). The process of financial liberalization is most intensifying in these markets and thus the contrasting effects of long-term versus short-term capital flows, if any, would be most transparent in these countries.

Foreign direct investment (FDI), an important part of foreign investment, has been found to deliver growth-enhancing effects to the recipient countries. Aitken and Harrison (1999), for instance, argue that firms with higher foreign ownership have high productivity as they benefits from the foreign investors' possession of intangible productive assets, such as technological know-how, marketing and managing skills, export contacts, coordination with suppliers and customers, and reputation. Romer (1993) and Rappaport (2000) go a step further to suggest that foreign investment may boost the productivity of all firms, not just those receiving foreign capital. They argue that foreign investment can ease the transfer of technological and business know-how to poorer countries. These transfers may have substantial spillover effects for the entire countries. Stiglitz (1999, 2000, 2004) stresses the stability and strategic nature of FDI over other forms of foreign investment as the crucial element in ensuring the host countries get benefits from FDI.

Recent studies on the relation between FDI and growth emphasizes the importance of the host country's 'absorptive capacity'. This could be the level of financial development (Alfaro et al., 2004), the level of human capital (Borensztein, De Gregorio, \& Lee, 1998), or the level of trade openness (Balasubramanyam, Salisu, \& Dapsoford, 1996).

In this paper, we reinvestigate the effect of FDI on economic growth in emerging markets using improved model specifications and regression techniques in contrast to previous studies. In addition to the OLS regressions, we employ the random-effects regressions to account for the cross-sectional and time variation in the data. We introduce a financial liberalization factor to account for its possible impact on growth. The use of the financial liberalization variable is motivated by Bekaert, Harvey, and Lundblad (2005) study, which finds that liberalization is positively related to economic growth. A distinguishing feature of the emerging markets is that these countries have experienced a rapid liberalization process over the last two decades. Bekaert et al. (2005) find that equity market liberalizations lead to increase in annual real economic growth. In order to control for the 
possible liberalization effect on growth in emerging markets, we construct a Liberalization Intensity measure, which follows the methodology by Bekaert et al. (2005) and Edison and Warnock (2003).

In general, we find that the ratio of FDI inflows to total GDP itself is not related to economic growth for the sample of emerging markets, even though we consider different model specifications. But its interaction with trade or financial development of the host country is positively related to economic growth in some of the models we considered in this paper. The results confirm the importance of the absorptive capacity of the host country for the success of FDI.

This paper is the first study that controls for the financial liberalization effect on economic growth. Financial liberalization and the flows of FDI are often seen to come side-by-side. It is possible that the effect of FDI on economic growth to some extent is shared by the effect of financial liberalization on economic growth. Bekaert et al. (2005) find that financial liberalization is positively related to economic growth. We use a measure of financial liberalization, the so called Liberalization Intensity, which is used in Bekaert et al.'s and Warnock's (2003) papers, as a control variable in the growth regressions.

The inclusion of a financial liberalization indicator has several benefits. First, it controls for the effects that liberalization has on economic growth. In this line, liberalization plays as an important control variable in addition to the standard set of control variables. Second, a financial liberalization indicator may approximate growth opportunities whereby governments of the host countries may time liberalization with periods of high economic activities (Bekaert et al., 2005). Thus, the inclusion of financial liberalization in FDI-growth regressions to some extent may help solve the endogenous problem associated with FDI and economic growth. Finally, as the financial liberalization intensity indicator measures the effects of short-term capital flows, its presence together with foreign direct investment, a type of long-term capital, help reflect the overall impact of foreign investment on growth as well as identify which force, short-term or long-term capital, is stronger.

Our database covers a broader range of period than previous studies. The sample span is from 1980 to 2004. We choose the starting time of 1980 to keep our study consistent with Bekaert et al.'s (2005). The main reason for us to follow their study is that they find a positive relation between financial liberalization and economic growth. In our paper, we employ one of their liberalization variables to control for the variation in economic growth that is due to the financial liberalization process in the host countries.

The organization of the paper is as follows. Section II describes data and methodology. Section III presents the findings for all emerging markets in the sample. Section IV concludes the paper.

\section{Data and Methodology}

\subsection{Data}

We first identify emerging markets as those specified by the Standard and Poor's Emerging Markets Database (EMDB), which covers a total of 35 emerging markets. For each of the identified market, we extract the country-level indicators from the World Bank's World Development Indicators Online database for the period 1980-2004. In order to run panel data regressions, we delete any observations which contain missing values in any of the relevant indicators. As such, our final sample covers 24 emerging markets, namely Argentina, Brazil, Chile, China, Colombia, Egypt, Hungary, India, Indonesia, Jordan, Malaysia, Mexico, Morocco, Nigeria, Oman, Pakistan, Peru, Philippines, South Africa, Sri Lanka, Thailand, Turkey, Venezuela, and Zimbabwe.

\subsection{Variables Used}

\subsubsection{Dependent Variable}

GDP per capita growth: is the annual percentage growth rate of GDP per capita based on constant local currency. GDP per capita is gross domestic product divided by mid-year population. GDP at purchaser's prices is the sum of gross value added by all resident producers in the economy plus any product taxes and minus any subsidies not included in the value of the products. It is calculated without making deductions for depreciation of fabricated assets or for depletion and degradation of natural resources.

\subsubsection{Independent Variables}

Foreign Direct Investment (FDI): is the ratio of net inflows of Foreign Direct Investment to Gross Domestic Products. Foreign direct investment are the net inflows of investment to acquire a lasting management interest (10 percent or more of voting stock) in an enterprise operating in an economy other than that of the investor. It is the sum of equity capital, reinvestment of earnings, other long-term capital, and short-term capital as shown in the balance of payments.

Log initial GDP: is the logarithm of real per capita gross domestic product in 1980. 
Log life expectancy: is the natural logarithm of life expectancy at birth, which indicates the number of years a newborn infant would live if prevailing patterns of mortality at the time of its birth were to stay the same throughout its life.

Population growth: is the annual growth rate of total population, which counts all residents regardless of legal status or citizenship-except for refugees not permanently settled in the country of asylum, who are generally considered part of the population of the country of origin.

Trade/GDP: is the sum of exports and imports of goods and services measured as a share of gross domestic product. Trade is considered to have impact on the standards of living. Using geographical factors as instruments for trade (Note 2), Frankel and Romer (1999) find that the exogenous component of trade has a quantitatively large and robust, though only moderately statistically significant, positive effect on income.

Government consumption/GDP: is the ratio of government consumption to gross domestic product. General government final consumption expenditure (formerly general government consumption) includes all government current expenditures for purchases of goods and services (including compensation of employees). It also includes most expenditures on national defense and security, but excludes government military expenditures that are part of government capital formation.

Market capitalization: is the ratio of total market capitalization of listed companies to gross domestic product.

Private credit/GDP: is the ratio of domestic private credit to gross domestic product. Domestic credit to private sector refers to financial resources provided to the private sector, such as through loans, purchases of non-equity securities, and trade credits and other accounts receivable, that establish a claim for repayment. For some countries these claims include credit to public enterprises. This variable measures the level of financial development of a country. Levine, Loayza, and Beck (2000), Beck, Levine, and Loayza (2000) find that the exogenous component of financial intermediary development is positively related with economic growth. This finding is supported by many other studies on the finance-growth link (King \& Levine, 1993a, b), Rajan and Zingales (1998), Demirguc-Kunt and Maksimovic (1998), and Jayaratne and Strahan (1996).

Secondary school enrollment: is the ratio of total enrollment, regardless of age, to the population of the age group that officially corresponds to the level of education shown. Secondary education completes the provision of basic education that began at the primary level, and aims at laying the foundations for lifelong learning and human development, by offering more subject- or skill-oriented instruction using more specialized teachers. This variable approximates the level of human capital development, which is found to affect economic growth (Benhabib \& Spiegel, 1994) (Note 3).

Liberalization Intensity: is the ratio of the market capitalization of the constituent firms comprising the IFC Investable index to those that comprise the IFC Global index for each country. This measure is used in Bekaert et al. (2005) and Edison and Warnock's (2003) papers. Bekaert et al. (2005) demonstrate that equity market liberalization (allowing foreign investors to transact in local securities and vice versa) increases economic growth. Using an indicator for equity market liberalization, they find that equity market liberalization leads to an approximate $1 \%$ increase in annual real per capita GDP growth.

\subsection{Descriptions of Statistics}

Table 1. Summary statistics

Panel A. Summary statistics

\begin{tabular}{llllll}
\hline Variable & Obs & Mean & Std. Dev. & Min & Max \\
\hline Real GDP growth & 812 & 1.8517 & 4.7019 & -16.5107 & 15.8112 \\
FDI Inflows & 768 & 1.6726 & 2.0370 & -2.7572 & 16.8928 \\
Private credit & 802 & 45.1945 & 30.7945 & 0.0000 & 165.7191 \\
Secondary school enrollment & 186 & 75.2441 & 21.4469 & 24.5516 & 110.5440 \\
Population growth & 850 & 1.7465 & 1.2425 & -3.2924 & 11.5159 \\
Trade & 813 & 66.0506 & 39.4870 & 11.5457 & 251.1389 \\
Life expectancy & 512 & 68.4688 & 7.2273 & 37.2129 & 79.3664 \\
Government consumptions & 809 & 15.3907 & 6.2394 & 2.9755 & 41.4761 \\
Liberalization intensity & 607 & 0.4387 & 0.4024 & 0.0000 & 1.0000 \\
\hline
\end{tabular}


Panel B. Correlation matrix

\begin{tabular}{|c|c|c|c|c|c|c|c|c|}
\hline & $\begin{array}{c}\text { FDI } \\
\text { Inflows }\end{array}$ & $\begin{array}{c}\text { Private } \\
\text { credit }\end{array}$ & $\begin{array}{c}\text { Secondary } \\
\text { school } \\
\text { enrollment }\end{array}$ & $\begin{array}{l}\text { Population } \\
\text { growth }\end{array}$ & Trade & $\begin{array}{c}\text { Log life } \\
\text { expectancy }\end{array}$ & $\begin{array}{l}\text { Government } \\
\text { consumptions }\end{array}$ & $\begin{array}{l}\text { Liberalization } \\
\text { intensity }\end{array}$ \\
\hline FDI Inflows & 1.0000 & & & & & & & \\
\hline Private credit & $0.1546^{*}$ & 1.0000 & & & & & & \\
\hline Secondary school enrollment & $0.3077^{*}$ & $0.2855^{*}$ & 1.0000 & & & & & \\
\hline Population growth & $-0.1753 *$ & -0.0623 & $-0.3234 *$ & 1.0000 & & & & \\
\hline Trade & $0.3516^{*}$ & $0.3705^{*}$ & $0.2653^{*}$ & $0.1148^{*}$ & 1.0000 & & & \\
\hline Log life expectancy & $0.2111^{*}$ & $0.1661^{*}$ & $0.4835^{*}$ & $-0.2857^{*}$ & $0.1951^{*}$ & 1.0000 & & \\
\hline Government consumptions & 0.0159 & $0.1845^{*}$ & 0.2298 & $0.2330^{*}$ & $0.3223 *$ & 0.0616 & 1.0000 & \\
\hline Liberalization intensity & $0.2855^{*}$ & $0.1427 *$ & $0.3724 *$ & $-0.3102^{*}$ & 0.1028 & $0.3111 *$ & 0.0104 & 1.0000 \\
\hline
\end{tabular}

Note. * Indicates significant at the 0.05 level (using Bonferroni adjustment). Real GDP growth is the growth rate of real per capital gross domestic product. FDI Inflows is the ratio of Foreign Direct Investment inflows to Gross Domestic Product. Life expectancy is the number of years a person would live (Log life expectancy is the natural logarithm of life expectancy). Population growth is the growth rate of total population. Trade is the ratio of trade (exports + imports) to GDP. Private credit is the total credit to the private sector as a percentage of GDP. Government consumptions is the ratio of government consumptions to GDP. Liberalization intensity is the ratio of the market capitalization of the foreign investable portfolio to the market capitalization of the portfolio of all listed shares in the domestic stock exchange. Secondary school enrollment is the ratio of secondary school enrolment to the total secondary school-aged population.

Table 1 describes summary statistics and correlations of the main variables for all country-year observations. In Panel A, the mean growth rate of real per capita GDP in the sample is $1.85 \%$, with a standard deviation of $4.75 \%$. The average FDI inflow is $1.67 \%$ of total GDP. The maximum value of FDI inflow among the country-year observations is $16.89 \%$, whereas the minimum is $-2.76 \%$, indicating an outflow of FDI. The degree of openness, measured the liberalization intensity indicator, shows that approximately $43.87 \%$ of the total market capitalization are accessible to foreign investors.

The FDI inflows column in Panel B shows that FDI is highly and significantly correlated with secondary school enrollment and trade with the corresponding correlation coefficients being 0.3077 and 0.3516 , respectively. A negative correlation between FDI and population growth (coefficient of -0.1753) indicates that higher growth rate of population is associated with lower FDI inflows. FDI is also significantly related with private credit, $\log$ life expectancy, and liberalization intensity. Looking across, we observe that the independent variables are highly interrelated. This is not surprising as the literature on economic growth has highly correlated variables, which to some extent captures the overlapping aspects of the overall macroeconomic picture of a country.

\subsection{Methodology}

We employ the panel data regression technique in order to take into account the time and cross-country variability $\mathrm{f}$ thenature o data. In particular, we run the following random-effects regressions of growth on FDI, control variables and interaction terms:

$$
\text { Growth }_{i, t}=\beta_{1} F D I_{i, t}+\beta_{2} F D I_{i, t} * D E V_{i, t}+\beta_{3} D E V_{i, t}+\beta_{4} X_{i, t}+\eta_{i}+\varepsilon_{i, t}
$$

where Growth is the real per capita growth rate; $D E V$ is a development indicator representing the level of human capital stock, macroeconomic reforms, and the private sector development. X represents a set of controlled variables other than those specified above; $\eta$ is an unobserved country-specific effect; $\varepsilon$ is the error term; and subscripts $i$ and $t$ represent country and time period, respectively.

\section{FDI and Economic Growth: Empirical Evidence}

\subsection{Preliminary Analysis}

Our initial analysis investigates the relation between FDI and average economic growth rate in the presence of a standard set of control variables, which include initial GDP, life expectancy, population growth, government consumption, and liberalization intensity. We examine three alternative model specifications. Firstly, we treat all country-year observations equally, regardless of their time-series and cross-sectional nature. We then estimate the coefficients on the independent variables using OLS method. We report the regression results in columns (1) of Table 2.

Secondly, we employ the random-effects model to account for the panel structure of the data. We report the random-effects regression results in columns (2) of Table 2. Finally, we calculate the sample-period averages of 
all the variables and obtain an observation per country for all countries in the sample. We run OLS regressions based on those averages and report the results in columns (3) of Table 2.

Table 2. Regressions of economic growth on FDI using a standard set of control variables

\begin{tabular}{|c|c|c|c|c|c|c|}
\hline & \multicolumn{3}{|c|}{ PANEL A: With liberalization indicator } & \multicolumn{3}{|c|}{ PANEL B: Without liberalization indicator } \\
\hline & (1) & $(2)$ & $(3)$ & (1) & $(2)$ & (3) \\
\hline \multirow[t]{2}{*}{ Constant } & -21.374 & -25.629 & -32.107 & -31.573 & -15.805 & -32.311 \\
\hline & $(-2.06)^{b}$ & $(-3.13)^{\mathrm{a}}$ & $(-3.51)^{\mathrm{a}}$ & $(-4.55)^{\mathrm{a}}$ & $(-1.96)^{b}$ & $(-3.81)^{2}$ \\
\hline \multirow[t]{2}{*}{ FDI Inflows } & 0.094 & 0.070 & 0.167 & 0.120 & 0.194 & 0.172 \\
\hline & $(1.29)$ & $(0.75)$ & $(0.57)$ & $(1.66)^{\mathrm{c}}$ & $(2.58)^{\mathrm{a}}$ & $(0.62)$ \\
\hline \multirow[t]{2}{*}{ Log initial GDP } & -1.114 & -1.019 & -1.678 & -1.469 & -1.030 & -1.742 \\
\hline & $(-5.36)^{\mathrm{a}}$ & $(-3.84)^{\mathrm{a}}$ & $(-4.45)^{\mathrm{a}}$ & $(-7.94)^{\mathrm{a}}$ & $(-3.59)^{\mathrm{a}}$ & $(-5.44)^{2}$ \\
\hline \multirow[t]{2}{*}{ Log life expectancy } & 8.271 & 8.920 & 11.025 & 10.569 & 6.075 & 11.102 \\
\hline & $(3.14)^{\mathrm{a}}$ & $(4.29)^{\mathrm{a}}$ & $(4.42)^{\mathrm{a}}$ & $(5.77)^{\mathrm{a}}$ & $(2.94)^{\mathrm{a}}$ & $(4.76)^{\mathrm{a}}$ \\
\hline \multirow[t]{2}{*}{ Population growth } & -0.938 & -0.350 & -0.901 & -0.277 & 0.059 & -0.853 \\
\hline & $(-4.04)^{\mathrm{a}}$ & $(-1.28)$ & $(-2.26)^{b}$ & $(-1.85)^{\mathrm{c}}$ & $(0.37)$ & $(-2.37)^{\mathrm{b}}$ \\
\hline \multirow[t]{2}{*}{ Gov./GDP } & -0.042 & -0.066 & 0.141 & 0.044 & -0.023 & 0.142 \\
\hline & $(-1.04)$ & $(-1.58)$ & $(2.87)^{\mathrm{a}}$ & $(1.67)^{\mathrm{c}}$ & $(-0.63)$ & $(2.84)^{\mathrm{a}}$ \\
\hline \multirow[t]{2}{*}{ Liberalization } & -1.720 & -1.280 & -0.537 & & & \\
\hline & $(-3.57)^{\mathrm{a}}$ & $(-2.87)^{\mathrm{a}}$ & $(-0.40)$ & & & \\
\hline R-squared & 0.315 & 0.543 & 0.650 & 0.240 & 0.395 & 0.647 \\
\hline No. of obs & 216 & 216 & 28 & 295 & 295 & 28 \\
\hline
\end{tabular}

Note. ${ }^{\mathrm{a}}{ }^{\mathrm{b}}$, and ${ }^{\mathrm{c}}$ denote significance at the $1 \%, 5 \%$, and $10 \%$ levels, respectively. Column (1) shows the results from the pooled OLS regression. Column (2) shows the result from the random-effects regression. Column (3) shows the results from the OLS regression on the country averages data. The dependent variable is the next 5 -year average growth rate of real per capital gross domestic product. FDI is the ratio of Foreign Direct Investment inflows to Gross Domestic Product. Log initial GDP is the log real per capita GDP level in 1980. Log life expectancy is the log life expectancy of the total population; population growth is the growth rate of total population; trade/GDP is the ratio of trade (exports + imports) to GDP; private credit/GDP is the total credit to the private sector as a percentage of GDP; gov. cons./GDP is the ratio of government consumption to GDP; liberalization is the ratio of the market capitalization of the foreign investable portfolio to the market capitalization of the portfolio of all listed shares in the domestic stock exchange; secondary school enrollment is the ratio of secondary school enrolment to the total secondary school-aged population. Values in the bracket are t-statistics in columns (1) and (3) and z-statistics in columns (2).

The results across all columns of Panel A, Table 2 consistently show that FDI inflows, as a percentage of GDP, are not related to five-year average growth rate of GDP per capita. Interestingly, two of the three regressions in Panel A indicate a negative association between financial liberalization and economic growth (columns (1) and (2). Economically, column (2) implies that a country's economic growth rate per capita would decrease by approximately $1.28 \%$ if its stock market moved from completely close to completely open to foreign investors.

The lack of relation between FDI and economic growth may be due to the presence of the financial liberalization indicator in the regressions. Most of previous studies, which do not control for the effects of financial liberalization on economic growth, find that FDI is positively related to economic growth (for instance, Teece (1997), and Romer (1993). We remove the financial liberalization indicator and rerun the regressions to test whether FDI, in the absence of financial liberalization effect, is related to economic growth in our sample. The results in column (1) and column (2) show that FDI is positively related to economic growth, though the coefficient on FDI inflows is only significant at the 0.10 level. Column (3), which reports the regression result using the country-average data, does not indicate a significant relation between FDI and growth.

The results in Table 2 suggest the importance of taking into account the effect of financial liberalization on economic growth. A study by Bekaert et al. (2005) finds that equity market liberalizations are positively associated with economic growth. While the results in Table 2 show a negative relation between liberalization and growth, they are not necessarily inconsistent with Bekaert et al.'s (2005) finding. Bekaert et al. (2005) look at a larger sample (95 countries) and a different time period (1980-1997). 


\subsection{FDI and the Financial Environment}

Alfaro et al. (2004) argue that a country can only reap the benefits from FDI if it has a sufficient level of financial development. In this section, we use the ratio of the total credit to the private sector to GDP as a measure of financial development. This measure is used to proxy for financial development in many studies on economic growth (for example, Bekaert et al., 2005; Levine et al., 2000). We also create an interactive variable that represents the interaction between FDI and the level of financial development.

Panel A of Table 3 reports the results from the pooled OLS regressions where the level of financial development, or its interaction with FDI, or both, are present. Across all three columns, we find no relation between the ratio of FDI inflows to GDP and economic growth. However, the interaction between FDI and the level of financial development is positively and significantly related to economic growth at the $5 \%$ level (column 3 ). This effect is due more to the positive effect of private credit on growth than to the FDI effect. In column (1), the coefficient on private credit is 0.0193 and significant at the $5 \%$ level.

Table 3. FDI and financial environment

\begin{tabular}{|c|c|c|c|c|c|c|c|c|c|}
\hline & \multicolumn{3}{|c|}{ PANEL A: Pooled OLS regressions } & \multicolumn{3}{|c|}{$\begin{array}{c}\text { PANEL B: Random-effects } \\
\text { regressions }\end{array}$} & \multicolumn{3}{|c|}{$\begin{array}{c}\text { PANEL C: Country-average } \\
\text { regressions }\end{array}$} \\
\hline & $(1)$ & $(2)$ & (3) & $(1)$ & $(2)$ & (3) & $(1)$ & (2) & (3) \\
\hline \multirow[t]{2}{*}{ Constant } & -17.587 & -18.018 & -15.999 & -22.180 & -22.612 & -21.577 & -27.379 & -24.637 & -21.751 \\
\hline & $(-1.80)^{\mathrm{c}}$ & $(-1.68)^{\mathrm{c}}$ & $(-1.38)$ & $(-3.06)^{\mathrm{a}}$ & $(-3.02)^{\mathrm{a}}$ & $(-2.90)^{\mathrm{a}}$ & $(-3.68)^{\mathrm{a}}$ & $(-2.26)^{b}$ & $(-2.08)^{b}$ \\
\hline \multirow[t]{2}{*}{ FDI Inflows } & 0.059 & 0.087 & -0.134 & 0.074 & 0.098 & -0.020 & -0.065 & -0.320 & -0.618 \\
\hline & $(0.88)$ & $(0.55)$ & $(-1.12)$ & $(0.83)$ & $(0.62)$ & $(-0.16)$ & $(-0.27)$ & $(-0.64)$ & $(-1.55)$ \\
\hline \multirow[t]{2}{*}{ Log initial GDP } & -1.020 & -1.031 & -0.976 & -1.025 & -1.033 & -1.006 & -1.425 & -1.334 & -1.253 \\
\hline & $(-5.55)^{\mathrm{a}}$ & $(-4.99)^{\mathrm{a}}$ & $(-4.62)^{\mathrm{a}}$ & $(-4.76)^{\mathrm{a}}$ & $(-4.66)^{\mathrm{a}}$ & $(-4.54)^{\mathrm{a}}$ & $(-4.28)^{\mathrm{a}}$ & $(-3.60)^{\mathrm{a}}$ & $(-3.22)^{\mathrm{a}}$ \\
\hline \multirow[t]{2}{*}{ Log life expectancy } & 7.128 & 7.233 & 6.833 & 8.149 & 8.251 & 8.052 & 9.479 & 8.806 & 8.151 \\
\hline & $(2.94)^{\mathrm{a}}$ & $(2.73)^{\mathrm{a}}$ & $(2.36)^{\mathrm{b}}$ & $(4.41)^{\mathrm{a}}$ & $(4.33)^{\mathrm{a}}$ & $(4.24)^{\mathrm{a}}$ & $(4.99)^{\mathrm{a}}$ & $(3.24)^{\mathrm{a}}$ & $(3.03)^{\mathrm{a}}$ \\
\hline \multirow[t]{2}{*}{ Population growth } & -0.909 & -0.894 & -1.028 & -0.646 & -0.626 & -0.691 & -0.697 & -0.762 & -0.873 \\
\hline & $(-4.04)^{\mathrm{a}}$ & $(-3.56)^{\mathrm{a}}$ & $(-4.11)^{\mathrm{a}}$ & $(-2.80)^{\mathrm{a}}$ & $(-2.59)^{\mathrm{a}}$ & $(-2.93)^{\mathrm{a}}$ & $(-1.97)^{b}$ & $(-1.90)^{\mathrm{c}}$ & $(-2.38)^{b}$ \\
\hline \multirow[t]{2}{*}{ Gov/GDP } & -0.082 & -0.083 & -0.056 & -0.069 & -0.071 & -0.056 & 0.062 & 0.065 & 0.080 \\
\hline & $(-1.81)^{\mathrm{c}}$ & $(-1.84)^{\mathrm{c}}$ & $(-1.35)$ & $(-1.76)^{\mathrm{c}}$ & $(-1.75)^{\mathrm{c}}$ & $(-1.44)$ & $(0.98)$ & $(0.97)$ & $(1.53)$ \\
\hline \multirow[t]{2}{*}{ Liberalization } & -1.713 & -1.709 & -1.747 & -1.506 & -1.499 & -1.481 & -1.135 & -1.217 & -1.241 \\
\hline & $(-3.86)^{\mathrm{a}}$ & $(-3.87)^{\mathrm{a}}$ & $(-3.75)^{\mathrm{a}}$ & $(-3.43)^{\mathrm{a}}$ & $(-3.41)^{\mathrm{a}}$ & $(-3.36)^{\mathrm{a}}$ & $(-0.93)$ & $(-0.97)$ & $(-0.96)$ \\
\hline \multirow[t]{2}{*}{ Private credit } & 0.019 & 0.021 & & 0.011 & 0.012 & & 0.028 & 0.017 & \\
\hline & $(2.45)^{\mathrm{b}}$ & (1.63) & & $(1.77)^{\mathrm{c}}$ & $(1.25)$ & & $(2.78)^{\mathrm{a}}$ & $(0.67)$ & \\
\hline \multirow[t]{2}{*}{ FDI * Private credit } & & -0.001 & 0.005 & & -0.001 & 0.002 & & 0.005 & 0.011 \\
\hline & & $(-0.17)$ & $(2.18)^{\mathrm{b}}$ & & $(-0.19)$ & (1.18) & & $(0.54)$ & $(3.12)^{\mathrm{a}}$ \\
\hline R-squared & 0.357 & 0.358 & 0.339 & 0.695 & 0.692 & 0.645 & 0.745 & 0.749 & 0.741 \\
\hline No. of obs & 216 & 216 & 216 & 216 & 216 & 216 & 28 & 28 & 28 \\
\hline
\end{tabular}

Note. ${ }^{\mathrm{a}},{ }^{\mathrm{b}}$, and ${ }^{\mathrm{c}}$ denote significance at the $1 \%, 5 \%$, and $10 \%$ levels, respectively. The dependent variable is the next 5 -year average growth rate of real per capital gross domestic product. FDI is the ratio of Foreign Direct Investment inflows to Gross Domestic Product. Log initial GDP is the log real per capita GDP level in 1980. Log life expectancy is the log life expectancy of the total population; population growth is the growth rate of total population; trade/GDP is the ratio of trade (exports + imports) to GDP; private credit/GDP is the total credit to the private sector as a percentage of GDP; gov. cons./GDP is the ratio of government consumption to GDP; liberalization is the ratio of the market capitalization of the foreign investable portfolio to the market capitalization of the portfolio of all listed shares in the domestic stock exchange; secondary school enrollment is the ratio of secondary school enrolment to the total secondary school-aged population. The figures in italic are the z-statistics.

In Panel B, we investigate the relation between FDI and economic growth using the random-effects models. Similar to the model specifications in Panel A, we look at the cases where the level of financial development enters the models as an independent variable or as an interaction with FDI or both. Again, all three columns in Panel B consistently show that FDI is not significantly related to economic growth. The interaction of financial development with FDI is not related to economic growth (columns (2) and (3). But the association between financial development and growth still exists albeit at the $10 \%$ level of significance. 
One noticeable feature across all columns of Panel A and Panel B is that financial liberalization is consistently negatively related to economic growth. The relation is strong and highly significant. The level of significance of the relation is always at the $1 \%$ level and the smallest coefficient on liberalization, in terms of absolute value, is -1.48 (column (3).

The results from the OLS regressions using country-averaged data confirm an earlier finding that there is no significant relation between FDI inflows and economic growth (Panel C). The level of financial development is positively related to economic growth when the interaction term is not in the regression (column 1). When the level of financial development is not in the regression as in column 3, the interaction term is positively related to economic growth. The latter positive relation is driven by the strong association between the level of financial development and economic growth rather than FDI effects. The financial liberalization indicator in Panel C is no longer significantly related to economic growth.

In summary, the analysis of the FDI-growth nexus under the influence of a country' financial development shows that this link does not exist, in other words, FDI is not significantly related to economic growth. This finding is consistent with Carkovic and Levine (2005). The positive relation between private credit and growth in the majority of regressions is consistent with the literature on finance and growth (for instance, Levine et al., 2000), and Rajan and Zingales (1998). The negative relation between financial liberalization and economic growth seems to contrast with the findings in Bekaert et al. (2005). We will discuss the role of financial liberalization on economic growth in section 2.5.

\subsection{FDI and Trade Opennesss}

Frankel and Romer (1999) find that trade has a significant effect on income. Similarly, Balasubramanyam et al. (1996) argue that trade openness is crucial for obtaining the growth-effects of FDI. Economic growth in export-orienting countries is higher than that in countries pursuing protectionist trade policy. In our growth regressions, we employ the ratio of trade, which is the sum of exports and imports, to GDP as proxy for a country's trade openness. As in many cases, FDI inflows are allocated to export-orienting industries, FDI-induced benefits may be magnified in countries that promote exports. We therefore create an interaction term between FDI and trade openness to examine this potential impact on growth.

Similar to the previous section, we report the regression results in three panels in Table 4. Panel A shows the OLS regression results when we treat all country-year observations equally. Panel B shows the random-effect regression results and Panel C shows the OLS regression results for the country averages.

In the first two model specifications in Panel A, the coefficient on FDI is insignificant. The third model specification shows a significant relation between FDI and economic growth at the 5\% level, but this relation is negative (coefficient of -0.28). The relation between the interaction term and growth, however, is positive. In order for the overall relation between FDI and growth is positive, the level of trade openness must be at least 73.29\%. From Panel C of Table 1, the following countries have higher trade openness threshold and therefore are beneficial from FDI: Bahrain (trade openness of 175.34\%), Czech Republic (114.54\%), Hungary (93.04\%), Israel (85.12\%), Jordan (119.96\%), Malaysia (159.31\%), Oman (87.26\%), Philippines (73.90\%), Slovak Republic (116.98\%), Sri Lanka (74\%), and Thailand (82\%).

In Panel B, where the panel structure of the data is taken into account, the regression results across all three columns show that FDI is not related to economic growth. However, the coefficient on the interaction term is positive and significant, suggesting that the level of trade openness affects a country's ability to reap the FDI-induced benefits (column (3). Assuming an average country with a trade openness index of $66.84 \%$, an increase in FDI inflows by $1 \%$ would add around $0.20 \%$ to annual economic growth rate.

The OLS regressions using the country averages data show no relation between FDI and economic growth (Panel C). The interaction between FDI and trade openness as well as the level of trade openness do not enter the regressions significantly, either. These results may be due to the fact that we ignore the time variation in the variables with the average data.

In summary, FDI is generally not related to economic growth when the level of trade openness is taken into account. In one model specification, FDI is found to be associated with growth but the relation is negative. The positive relation between the interaction term and economic growth suggests that FDI plays a positive role when it interacts with the degree of trade openness. This seems to be consistent with the finding by Balasubramanyam et al. (1996), who find that FDI is related to growth when controlling for trade policy. Financial liberalization is found to be negatively associated with growth as in section 3.2. 
It is therefore important to consider the effects of liberalization in growth regressions. In our baseline regressions (see Table 2), we find that FDI is related to economic growth when liberalization is not present. The relation between FDI and growth is not significant when liberalization enters into the picture.

The inclusion of a financial liberalization indicator has several benefits. First, it controls for the effects that liberalization has on economic growth. In this line, liberalization plays an important part as a control variable in addition to the standard set of control variables. Second, a financial liberalization indicator may approximate growth opportunities whereby governments of the host countries may time liberalization with periods of high economic activities (Bekaert et al., 2005). Thus; the inclusion of financial liberalization in FDI-growth regressions to some extent may help solve the endogenous problem associated with FDI and economic growth. Finally, as the financial liberalization intensity indicator measures the effects of short-term capital flows, its present together with foreign direct investment, a type of long-term capital, helps reflect the overall impact of foreign investment on growth as well as identifying the stronger force between short-term and long-term capital.

The empirical results discussed so far show that short-term capital flows have a stronger influence on economic growth with the sign of the liberalization indicator being negative in most of the regressions. This negative relation seems to be inconsistent with Bekaert et al.'s (2005) paper which finds that equity market liberalizations lead to higher economic growth. Nevertheless, Bekaert et al. (2005) investigate a different period of time (19801997) and cover a larger sample (40 countries).

The negative relation between liberalization and growth is consistent with Bae, Chan, and Ng's (2004) and Stiglit's $(1999,2002,2004)$ studies, which argues that financial liberalization is associated with higher volatility. Bae et al. (2004) find that firm-level liberalization, or investability, is positively related to stock return volatility. Stiglitz $(1999,2002,2004)$ emphasizes that financial liberalization may lead to higher volatility because short-term capital flows are highly volatile. The author stresses the danger of the movement of the so-called hot money, that is, an international flow of funds allegedly highly sensitive to differences in interest rate, expectations of future economic growth, and expected returns from holding securities. Given the sensitivity of these investments, even a small shock to the economy can lead to a volatile change in fund flows, which exacerbates the shock and destabilizes the domestic economy. In addition, market opening means an exposure to foreign influence. If foreign stock prices are for some reason more volatile than domestic stock prices, domestic prices may also become more volatile. A greater volatility in stock prices would make investors more averse to holding stocks and lead them to demand a higher risk premium, which implies a higher cost of capital and less investment. Stiglitz $(1999,2002,2004)$ thus argues that financial liberalization leads to lower economic growth.

\section{Conclusions}

After investigating the relation between FDI and economic growth in emerging markets, we find no direct relation between these two variables. Rather, we find evidence of the role of FDI through its interaction with the host country's level of development. We find that the levels of financial development and trade openness of the host country are crucial to the success of FDI. We have too few data on the stock of human capital to reach a meaningful conclusion on the relation between FDI and growth under different levels of human capital stock.

Financial liberalization is found to be negatively associated with economic growth. This, together with the negative effect of the level of financial development, suggests that emerging markets' institutional structure is not strong enough to cope with the highly volatile nature of short-term capitals (Stiglitz, 1999, 2002, 2004). Future research on the FDI-growth nexus should control for the impact of financial liberalization on economic growth.

The paper has important implications for policy makers in emerging markets. Governments in these countries should increase the effectiveness of domestic institutions as well as design strategies and regulations that can maximize the benefits of foreign investments. Failure to manage the flows of foreign investments, especially foreign portfolio investments, could have disastrous consequences to the host countries.

\section{References}

Aitken, B., \& Harrison, A. (1999). Do domestic firms benefit from foreign investment? Evidence from Venezuela. American Economic Review, 89, 605-618. http://dx.doi.org/10.1257/aer.89.3.605

Alfaro, L. A., Chanda, A., Kalemli-Ozcan, S., \& Sayek, S. (2004). FDI and economic growth: The role of local financial markets. Journal of International Economics, 64, 89-112. http://dx.doi.org/10.1016/S0022-1996(03)00081-3

Bae, K. H., Chan, K., \& Ng, A. (2004). Investibility and return volatility. Journal of Financial Economics, 71, 239-263. http://dx.doi.org/10.1016/S0304-405X(03)00166-1 
Balasubramanyam, V., Salisu, M., \& Sapsford, D. (1996). Foreign Direct Investment and Growth in EP and IS Countries. Economic Journal, 106, 92-105. http://dx.doi.org/10.2307/2234933

Beck, T., Levine, R., \& Loayza, N. (2000). Finance and the sources of growth. Journal of Financial Economics, 58, 261-300. http://dx.doi.org/10.1016/S0304-405X(00)00072-6

Bekaert, G., Harvey, C., \& Lundblad, C. (2005). Does financial liberalization spur growth? Journal of Financial Economics, 77, 3-55. http://dx.doi.org/10.1016/j.jfineco.2004.05.007

Benhabib, J., \& Spiegel, M. (1994). The roles of human capital in economic development: evidence from aggregate cross-country data. Journal of Monetary Economics, 34, 143-173. http://dx.doi.org/10.1016/0304-3932(94)90047-7

Borensztein, E., De Gregorio, J., \& Lee, J. (1998). How does foreign investment affect growth? Journal of International Economics, 45, 115-135. http://dx.doi.org/10.1016/S0022-1996(97)00033-0

Brun, J. F., Carrère, C., Guillaumont, P., \& de Melo, J. (2005). Has distance died? Evidence from a panel gravity model. World Bank Economic Review, 19, 99-120. http://dx.doi.org/10.1093/wber/lhi004

Carkovic, M., \& Levine, R. (2005). Does foreign direct investment accelerate economic growth? In T. Moran, E. Graham \& M. Blomstrom (Eds.), Does foreign direct investment promote development? Institute for International Economics, Washington DC.

Chari, A., \& Henry, P. (2004). Risk sharing and asset prices: evidence from a natural experiment. Journal of Finance, 59, 1295-1324. http://dx.doi.org/10.1111/j.1540-6261.2004.00663.x

Demirguc-Kunt, A., \& Maksimovic, V. (1998). Law, finance, and firm growth. Journal of Finance, 53, $2107-$ 2137. http://dx.doi.org/10.1111/0022-1082.00084

Edison, H., \& Warnock, F. (2003). A simple measure of the intensity of capital controls. Journal of Empirical Finance, 10, 81-104. http://dx.doi.org/10.1016/S0927-5398(02)00055-5

Frankel, J., \& Romer, D. (1999). Does trade cause growth? Amercian Economic Review, 89, 379-399. http://dx.doi.org/10.1257/aer.89.3.379

Gupta, N., \& Yuan, K. (2006). On the growth effect of stock market liberalizations. Working paper, Indiana University and University of Michigan.

Henry, P. (2000). Do stock market liberalizations cause investment booms? Journal of Financial Economics, 58, 301-334. http://dx.doi.org/10.1016/S0304-405X(00)00073-8

Jayaratne, J., \& Strahan, P. (1996). The finance-growth nexus: evidence from bank branch deregulation. Quarterly Journal of Economics, 111, 639-670. http://dx.doi.org/10.2307/2946668

King, R., \& Levine, R. (1993a). Finance and growth: Schumpeter might be right. Quarterly Journal of Economics, 108, 717-738. http://dx.doi.org/10.2307/2118406

King, R., \& Levine, R. (1993b). Finance, entrepreneurship and growth: theory and evidence. Journal of Monetary Economics, 32, 513-542. http://dx.doi.org/10.1016/0304-3932(93)90028-E

Leamer, E., \& Levinsohn, J. (1995). International trade: The evidence. In G. Grossman \& K. Rogoff (Eds.), Handbook of international economics (Vol. 3). New York: Elsevier, North-Holland.

Levine, R., Loayza, N., \& Beck, T. (2000). Financial intermediation and growth: causality and causes. Journal of Monetary Economics, 46, 31-77. http://dx.doi.org/10.1016/S0304-3932(00)00017-9

Li, Z. (2003). Equity market liberalization and economic performance. Working Pper, Princeton University.

Mitton, T. (2006). Stock market liberalization and operating performance at the firm level. Journal of Financial Economics, 81, 625-647. http://dx.doi.org/10.1016/j.jfineco.2005.09.001

Nelson, R., \& Phelps, E. (1966). Investment in humans, technological diffusion, and economic growth. American Economic Review: Papers and Proceedings, 51, 69-75.

Rajan, R., \& Zingales, L. (1998). Financial dependence and growth. American Economic Review, 88, 559-586.

Rappaport, J. (2000). How does openness to capital flows affect growth? Working Paper RWP, 00-11, Federal Reserve Bank of Kansas City, December.

Romer, P. (1990). Endogenous technological change. The Journal of Political Economy, 98, 71-102. http://dx.doi.org/10.1086/261725 
Romer, P. (1993). Idea gaps and object gaps in economic development. Journal of Monetary Economics, 32, 543-573. http://dx.doi.org/10.1016/0304-3932(93)90029-F

Stiglitz, J. (1999). Reforming the global architecture: Lessons from recent crises. Journal of Finance, 54, 15081521. http://dx.doi.org/10.1111/0022-1082.00154

Stiglitz, J. (2000). Capital market liberalization, economic growth, and stability. World Development, 28, 10751086. http://dx.doi.org/10.1016/S0305-750X(00)00006-1

Stiglitz, J. (2004). Capital market liberalization, globalization and IMF. Oxford Review of Economic Policy, 20 , 57-71. http://dx.doi.org/10.1093/oxrep/grh004

\section{Notes}

Note 1. Chari and Henry (2004) regard stock market liberalization as a natural experiment.

Note 2. The relation between trade and geographical factors, such as distance, is well-known (Brun, Carrère, Guillaumont, and de Melo (2005). While other studies, for instance Leamer and Levinsohn (1995), find a puzzle that "the effect of distance on trade patterns is not diminishing over time", Brun et al. (2005) solve this puzzle by adding an augmented trade barrier to the traditional gravity model. With the modified gravity model, Brun et al. find that the effect of distance on trade decreases by approximately 11\% over the 1962-1996 period.

Note 3. Nelson and Phelps (1966) argue that the human capital stock affects the speed of adoption of technology from abroad. Romer (1990) adds that human capital levels directly influence the rate of domestically produced technological innovation.

\section{Copyrights}

Copyright for this article is retained by the author(s), with first publication rights granted to the journal.

This is an open-access article distributed under the terms and conditions of the Creative Commons Attribution license (http://creativecommons.org/licenses/by/3.0/). 